SCIENTIFIC JOURNAL OF POLISH NAVALACADEMY

2020 (LXI)

$3(222)$

sciendo

DOI: $10.2478 /$ sjpna-2020-0011

\title{
ICE DRIFT IN THE ARCTIC OCEAN
}

\section{Czesław Dyrcz $\mathbb{D}$}

Polish Naval Academy, Faculty of Navigation and Naval Weapons, Śmidowicza 69 Str., 81-127 Gdynia, Poland, e-mail: c.dyrcz@amw.gdynia.pl, ORCID ID: 0000-0002-5199-1241

\begin{abstract}
The paper presents results of research based on analysis of historical and present studies of the Arctic ice drift. Current information about Arctic ice drift comes from the scientific expedition organized by the Alfred-Wrgener-Institut Helmholtz Centre for Polar and Marine Research (AWI) from Bremerhaven (Germany) in the Arctic Ocean, as a part of the Multidisciplinary drifting Observatory for the Study of Arctic Climate (MOSAiC), coming from the deck of the icebreaker RV "Polarstern". The main purpose of the article was to collect and illustrate information on the phenomenon of ice drift in the Arctic Ocean, considering data from ongoing research during the MOSAiC expedition. The average movement speed of the icebreaker RV "Polarstern" frozen in Arctic ice during the first three legs of the expedition was over $5 \mathrm{Nm} /$ day, which is characteristic of the current data relating to the speed of the Arctic ice drift in the place of research. On the other hand, the article is popular science, and presents the overall characteristics of Arctic ice drift with an indication of the general directions, and speed of its movement. Ice drift speeds in the Arctic can reach exceptionally high values under favorable conditions. The drift of sea ice reaching at its intensity/intensity values close to the limit (dangerous criterion) in these extreme cases is called the "ice river". The speed of "ice rivers" can reach up to 1-2 knots, however, in extreme conditions up to 9 knots. Based on data from the AWI, correlation points were identified between the speed of Arctic ice drift and the speed of winds and atmospheric pressure values.
\end{abstract}

Keywords:

sea ice drift, Arctic ice drift, MOSAiC

Research article

(C) 2020 Czesław Dyrcz

This journal provides immediate open access to its content under the Creative Commons by 4.0 license. Authors who publish with this journal retain all copyrights and agree to the terms of the above-mentioned CC BY 4.0 license 


\section{INTRODUCTION}

The issue of ice drift in the Arctic Ocean has become particularly important recently, with extreme ice sheet melting during the Arctic summer, followed by freezing and movement. One of the problems studied for the current scientific expedition in the Arctic Ocean as part of MOSAiC is the drift of Arctic ice. It is now interesting information coming from the deck of the icebreaker RV "Polarstern", which is the base of the MOSAiC scientific expedition [7, 10,11]. During the historical period of research, the phenomenon of Arctic ice drift was carried out by many research expeditions, which did not always succeed. In addition, the results of scientific observations gained during each expedition increased our knowledge, and brought new information about these phenomena $[2,4,6,7,8,9,10,11,14,16]$.

According to W. Zakrzewski [16] the phenomenon of ice drift is the constant motion which is caused by the impact of winds, sea currents, and tidal currents on sea ice not permanently connected to the shore, or sea's bottom. The drift of ice in the sea is a complex, but nevertheless completely orderly phenomenon, and the following external forces influence the phenomenon of ice drift: the force of the wind on the surface of the ice; the force of the water on the drifting ice; the Coriolis force; a component gravity force parallel to the surface of the sea; the power of the interaction of ice floes [16]. The movement of ice can reach high values from a few to several knots. An example of the high speed of ice movement is the socalled "ice rivers", where ice masses have been observed to move up to 9 knots [9]. Observation of ice movement in the Arctic Ocean has been going on for centuries. The article will present three expeditions. The first one is the expedition of USS "Jeannette" commanded by lieutenant Georg W. De Long in the years 1879-1881 [14]. The second one is the expedition of the sailing ship "Fram" in Fridtjof Nansen charge of the scientific side in the years 1893-1896 [8]. The third expedition is currently ongoing MOSAiC, which is based on the RV icebreaker "Polarstern" organized by the Alfred Wegener Institute in 2019-2020 [7, 10,11]. The most important data for the modern estimation of the ice speed in the transpolar zone was provided by the research performed on the RV "Polarstern" $[7,10,11]$.

The main purpose of the article was to collect and illustrate information on the phenomenon of ice drift in the Arctic Ocean, taking into account data from ongoing research during the MOSAiC expedition. On the other hand, the article is a popular science, and presents the overall characteristics of Arctic ice drift with an indication of the general directions and speed of its movement. Following methods 
were used to achieve the above aim such an analysis of publications and inference. Implementation of the research was based on the historical material gathered by research institutes and present publications. It is worth emphasizing and highlighting the fact that the article is of a cognitive and popular science character.

The remainder of the paper is organized as follows: Section GENERAL CHARACTERISTICS OF SEA ICE DRIFT gives the description of forces influence the phenomenon of ice drift. Section ICE DRIFT RESERCH IN THE ARCTIC OCEAN presents three research expedition in the Arctic Ocean. Section DRIFT OF ICEBREAKER RV "POLARSTERN" IN THE ARCTIC ICE provides Arctic ice drift observation data, along with the meteorological data necessary to analyse the phenomenon. Finally, some discussion, and conclusions are given in last section.

\section{GENERAL CHARACTERISTICS OF SEA ICE DRIFT}

The impact of winds, sea currents, and tidal currents on sea ice are not permanently connected to the shore or sea's bottom to be in constant motion, which is called drift. The drift of ice in the sea is a complex, but nevertheless completely, orderly phenomenon [16, p. 69]. According to W. Zakrzewski, the following external forces influence the phenomenon of ice drift [16, p. 69-75]:

- the force of the wind on the surface of the ice;

- the force of the water on the drifting ice;

- the Coriolis force;

- a component gravity force parallel to the surface of the sea;

- the power of the interaction of ice floes.

Wind force on ice surface. This is, in most cases, the main force that causes the drift of sea ice. Because the ice protrudes slightly above the sea surface, and in addition, its upper surface is most often uneven, for example, covered with ice floors. The impact of wind on the surface of the ice is considered as: the force causing the wind to friction with a relatively flat surface of the ice; the force of the wind on the ice surface and wind surfaces, and the lateral surfaces of the coastal parts of the ice floors protruding over the side water. In order to understand the impact of wind on the flat surface of the ice at certain limits, it can be assumed that the wind speed of $\mathrm{V}_{\mathrm{w}}=10 \mathrm{~m} / \mathrm{s}$ affects an object with an area of $\mathrm{P}=1 \mathrm{~km}^{2}$ with a force of approximately $403000 \mathrm{~N}$, which corresponds to approximately $41100 \mathrm{kG}$. On the other hand, if 
the surface of the ice floe has ice concentrations (irregular surface) covering $10 \%$ of the area of the orifice, the wind force is approximately $884000 \mathrm{~N}$ for the above wind, and ice floe surface, equivalent to approximately $90150 \mathrm{kG}$. The value of this force is more than twice the value of the wind force on the flat surface of the ice, although ice floors occupy only $10 \%$ of the total ice surface [16, p. 69-72]. With high percentages of coverage of the surface of the icebergs, the wind force is up to 10 times higher.

The impact of water on drifting ice. The water in which the ice is submerged inhibits its movement. The drift of sea ice is opposed by the resistance of the submerged part of the ice floe to the water, and therefore its return is directed inversely to the direction of the ice drift. Of course, this force occurs when the speed of ice drift differs from the speed of the water flowing under the ice. The resistance of the submerged part of the ice floe to the water is the result of the frictional resistance forces formed between the lower surface of the flat ice and water, and the force of the frontal lateral resistance of the underwater surfaces of the ice floors, and the lateral surface of the submerged part of the ice floe. The example value of the frictional resistance force for drift ice floes with an area of $\mathrm{P}=1 \mathrm{~km}^{2}$, and the difference in ice drift speed, and water current speed of $\Delta \mathrm{v}=0,1 \mathrm{~m} / \mathrm{s}$ is approximately $101000 \mathrm{~N}$, corresponding to approximately $10300 \mathrm{kG}$ [16, p. 72 to 74]. The resistance strength of the drifting ice floss increases significantly with ice rises among drifting ice.

Coriolis force. The Coriolis force acts on drifting ice at a certain drift speed, as on any moving body in a rotating reference system. The value of Coriolis force depends on the ice mass, latitude, and speed of ice drift. Coriolis force value is highest at the pole, so its impact on the drift of ice in the Arctic Ocean has the greatest value, which is directly proportional to the sine of the angle of latitude. Since the speed of ice drift depends on the speed of the wind, the value of Coriolis force also depends on the wind speed. It is the higher in the higher the wind speed [16, p. 74].

Component gravity force parallel to the sea surface. If the water mirror is tilted at a certain angle from the level, which may occur during the wave, the gravity of the ice on the sea surface can be divided into the following two forces: a force perpendicular to the sea surface, and a force parallel to that surface. A component of the force of gravity parallel to the sea surface causes the ice floe to run down on this inclined surface of the sea.

Interaction of ice hearts. During ice drift, there is a continuous movement of ice floes relative to each other, as a result of which ice floes rub against each other, or collide. As a result, ice floes constantly transfer energy, which causes changes in the 
direction and speed of movement of individual ice hearts. The strength of mutual interaction of hearts depends on their mass, speed of movement, and ice compactness [16, p. 74].

The power of the interaction of ice floes. During the drift of ice, ice floes are in continuously movement relative to each other, as a result of which the mats rub against each other or collide with each other. As a result, ice floes are constantly transmitting energy to each other, which causes changes in the direction and speed of movement of individual ice floes. The force of the interaction of floes depends on their mass, speed of movement, and the content of the ice [16, p. 74].

Single ice floe drift caused by winds is rare, however, most often sea ice drifts within ice fields of various sizes and compactness. At a certain wind speed, the speed of ice field drift depends on the compactness of the ice, and the smaller it is, the greater the density of the ice. In the presence of high-density sea ice, the direct wind effect is limited to the ice surface, while the water surface is minimally affected; surface wind currents are very weak and do not support ice drift. In addition, the greater the ice density, the greater are the energy losses of individual ice hearts due to heart collisions, which further explains the slower ice floe drift with a high density compared to loose ice or single ice floes [16, p. 77].

The direction of ice field drift does not coincide with the direction of the blowing wind but is directed about 28-31을 to the right in the northern hemisphere due to the Coriolis force. The speed of sea ice drift and the sensitivity of their response to changes in wind speed, and direction depends on the mass of ice floes, the shape of their underwater and underwater parts, and ice content. The lighter the floe, and therefore smaller, or made of thinner ice, the faster it will be set in motion by the wind. When the wind stops, the smaller weight floes stop quickly. Large ice floes, as well as made of ice of very thick ice, have a significant mass, are more difficult to set in motion, while after the wind stops, they move much longer compared to parts of low mass. The speed of ice movement is significantly influenced by tidal currents.

Arctic ice drift speeds can be extremely high under favorable conditions. Sea ice drift reaching near its limit/intensity (dangerous criterion) in these extreme cases is called the "ice river". Intense ice drift and "ice river" are understood to mean drift of ice floes not less than $500 \mathrm{~m}$ in size at a speed of not less than 0.5 knots. The speed of the "ice river" can reach up to 1-2 knots, however, in extreme conditions up to 9 knots [6]. The phenomenon of "ice rivers" has a local character, and is often not detectable by traditional ice reconnaissance maps or by calculation.

3 (222) 2020 
This is mainly due to the small spatial and temporal dimensions of this phenomena, and to the large changes in ice drift speed as a function of time and space. The phenomenon of the "ice river" has not yet been statistically well studied. To date, only about one hundred such cases have been registered. Detection of this phenomenon by ships was often accompanied by critical and/or emergency events [9, p. 192193]. Ice drifting in the "ice river" at such a high speed is encountered, among others, on the Northern Sea Route, which is part of the Northeast Passage. "Ice rivers" are dangerous ice phenomenon for ships, and even icebreakers, which, in some cases, were unable to resist their impact.

The pack-ice motion process is associated with [13]:

- diverging (the process of loosening drift ice, leading to a decrease in ice density or stress occurring in it). During the ice deformation processes, fractures (figure 1), cracks, leads, and hummocks occur;

- compacting (decreasing the spacing between floes, resulting in increased ice firmness or the formation of stress that can lead to ice deformation). During compacting process, hummocking, ridging, and rifting occur;

shearing (displacement of floes relative to each other, which can cause rotational movement of floes and the formation of cracks filled with compact ice).

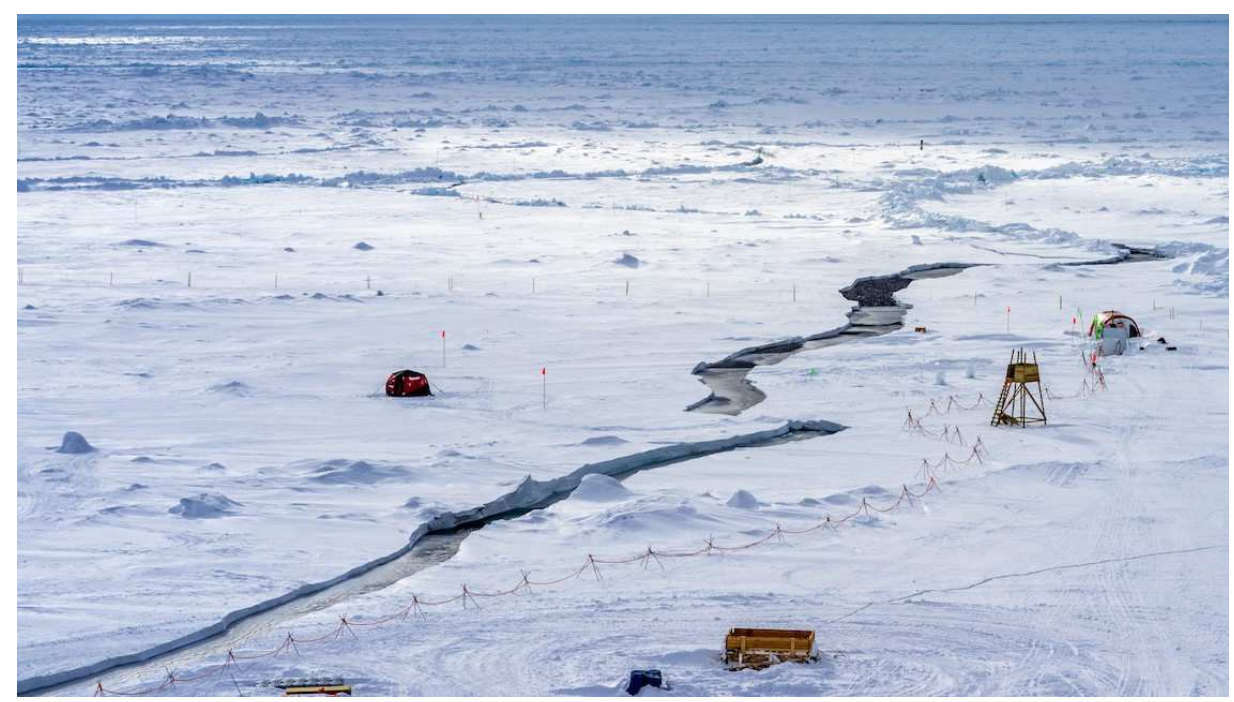

Figure 1. Ice break (fracture) observed from the icebreaker RV "Polarstern" on 10 May 2020 separating part of the "ice camp" from the base

(Source: photo by Christian Rohleder/Alfred-Wegener-Institut.) 


\section{ICE DRIFT RESEARCH IN THE ARCTIC OCEAN}

Observation of ice mass movement in the Arctic Ocean, and scientific research of this phenomenon have been conducted for a long time. The article will present three expeditions bringing significant value to this issue:

1. Expedition of USS "Jeannette" commanded by lieutenant Georg W. De Long in the years 1879-1881;

2. Expedition of the sailing ship "Fram" in Fridtjof Nansen charge of the scientific side in the years 1893-1896;

3. Currently ongoing MOSAiC expedition based on the RV icebreaker "Polarstern" organized by the Alfred Wegener Institute in 2019-2020.

The steam and sailing ship USS "Jeannette" sailed under the command of lieutenant Georg W. De Long in 1879 to the Arctic Ocean to reach the North Pole and discover unknown water spaces. The expedition ended with the destruction by ice and sinking of the USS "Jeannette" in June 1881 (figure 2), and death of a large part of the 33-man crew. Three years after the sinking of the USS "Jeannette", its remains were discovered on an ice floe near Julianehaab in southwestern Greenland. This floe with debris moved with the powerful polar current from the Novosibirsk Islands, passing from the north of the islands the Land of Franz Josef, Spitsbergen, most likely around the North Pole, and then along with the East Greenland current along the eastern coast of Greenland to Cape Farvel, and beyond west. The distance from the Novosibirsk Islands to Julianehaab along the route shown is approximately 2900 nautical miles. The remains of the USS "Jeannette" traveled this route in 1100 days, which indicates an average travel speed of $2.6 \mathrm{NM} /$ day [8]. 


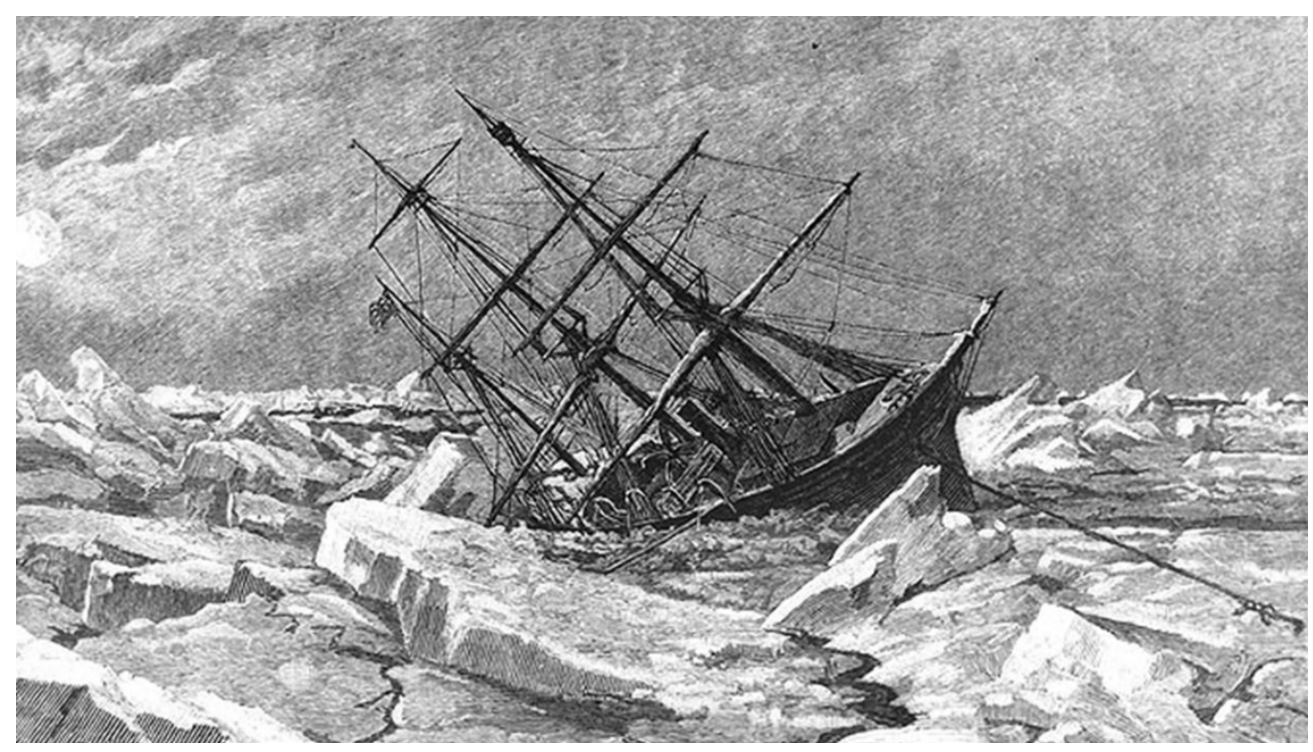

Figure 2. Destroyed by Arctic ice and sinking USS "Jeannette" in position north-east of the Novosibirsk Islands in June 1881

(Source: USS "Jeannette", Log Book of the Unated States Navy, Naval History Homepage.)

The MOSAiC expedition was preceded 127 years ago by the expedition of the Norwegian polar explorer Fridtjof Nansen, who set off on a long-term research expedition of the Arctic Ocean on a wooden sailing ship "Fram" (figure 3). The drift in the Arctic ice lasted from September 1893 to 1896. The purpose of the expedition of Fridtjof Nansen was to study the surrounding north pole of the basin on the route from the Novosibirsk Islands, as far north as possible, and then drift in the polar ice to the northwest [7]. 


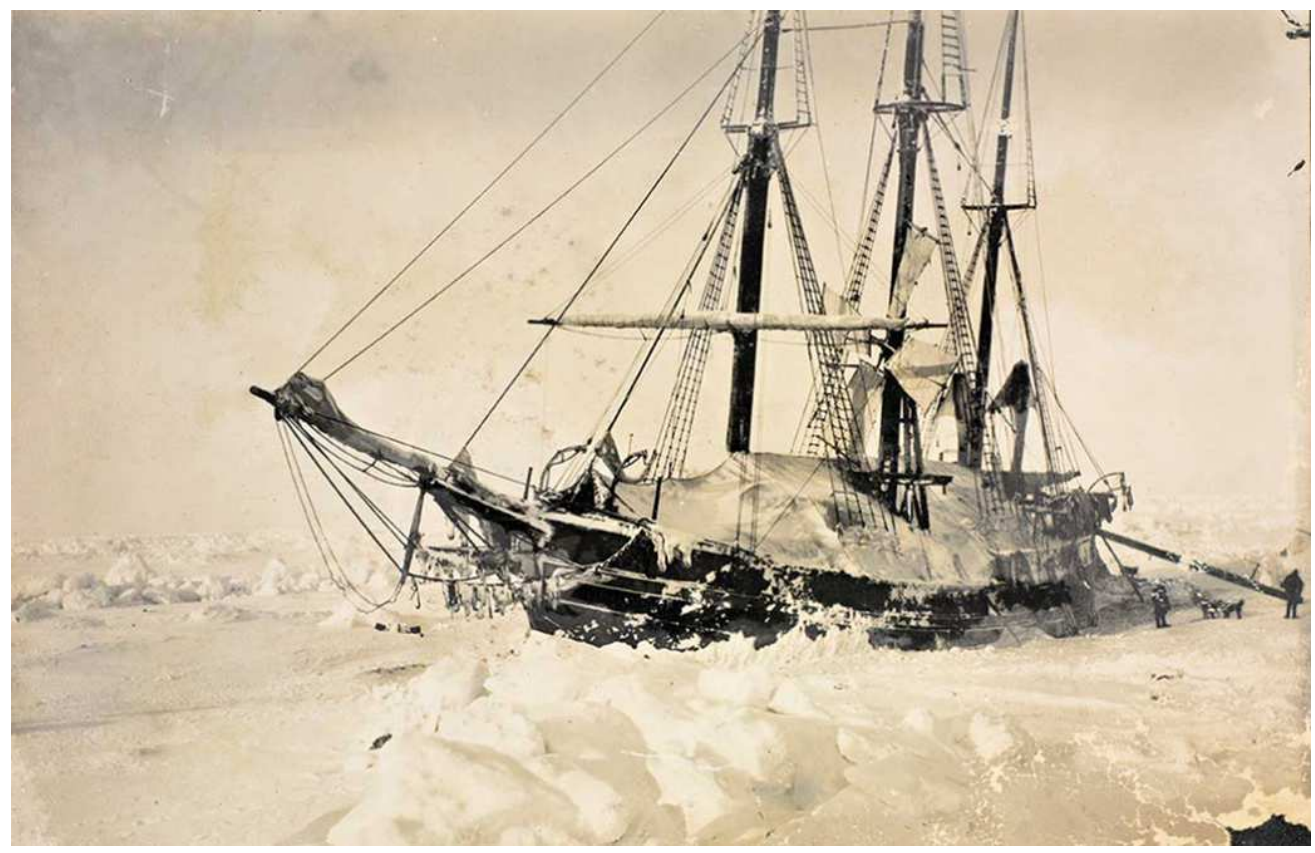

Figure 3. Drifting Norwegian sailing ship "Fram" in the ice of the Arctic Ocean during the Fridtjof Nansen expedition in the years 1893-1896

(Source: MOSAiC [8].)

In September 2019, the icebreaker RV "Polarstern" began an annual research expedition in the North Pole area called MOSAiC, and from October 4, 2019, after taking position, it drifts along with polar ice. The ship was built in 1982 in Kiel and Rendsburg (Germany). Basic unit data: length $117.91 \mathrm{~m}$, width $25.07 \mathrm{~m}$, draft $11.21 \mathrm{~m}$, displacement 17277 t, 4 diesel engines with a total power of $19000 \mathrm{HP}$ (14 $000 \mathrm{~kW}$ ), speed 15.5 knots. The ship is a research icebreaker ran by Alfred Wegener Institute (AWI) from Bremerhaven. The icebreaker is mainly used for research in the Arctic and Antarctic. During this largest research project in recent years, multidisciplinary studies of the atmosphere, sea ice, oceanography, ecosystem, and bio-chemical will be conducted. Observations are expected to reflect the complex mechanisms associated with climate change.

MOSAiC is the first year-long expedition to the central part of the Arctic Ocean, exploring the Arctic climate system. The project was prepared by an international consortium of leading polar research institutes, led by AWI. Around the icebreaker frozen in ice, research stations are located within a radius of several dozen kilometers. In addition, data is collected by research planes and vessels co- 
operating as part of the expedition. Research conducted with such impetus will allow a better understanding of Arctic climate change, and its contribution to global warming.

The first leg of the MOSAiC research expedition was completed on December 16, 2019 with the replacement of the research team, and icebreaker crew members. The exchange and supply took place through the Russian icebreaker "Captain Dranitsyn", who approached the RV "Polarstern" on December 13, 2019, and the break-off of icebreakers took place on December 18, 2019. The second leg was continued in the conditions of polar winter, that is, the darkest and coldest period in the Arctic. On December 29, 2019, the air temperature dropped to below $33^{\circ} \mathrm{C}$, and the felt temperature was around $-50^{\circ} \mathrm{C}$. In mid-November, the research area of the "Polarstern" icebreaker was in the presence of storm winds reaching a speed of about $25 \mathrm{~m} / \mathrm{s}$, which affected the deployed equipment in the "ice camp" [7, $10,11]$.

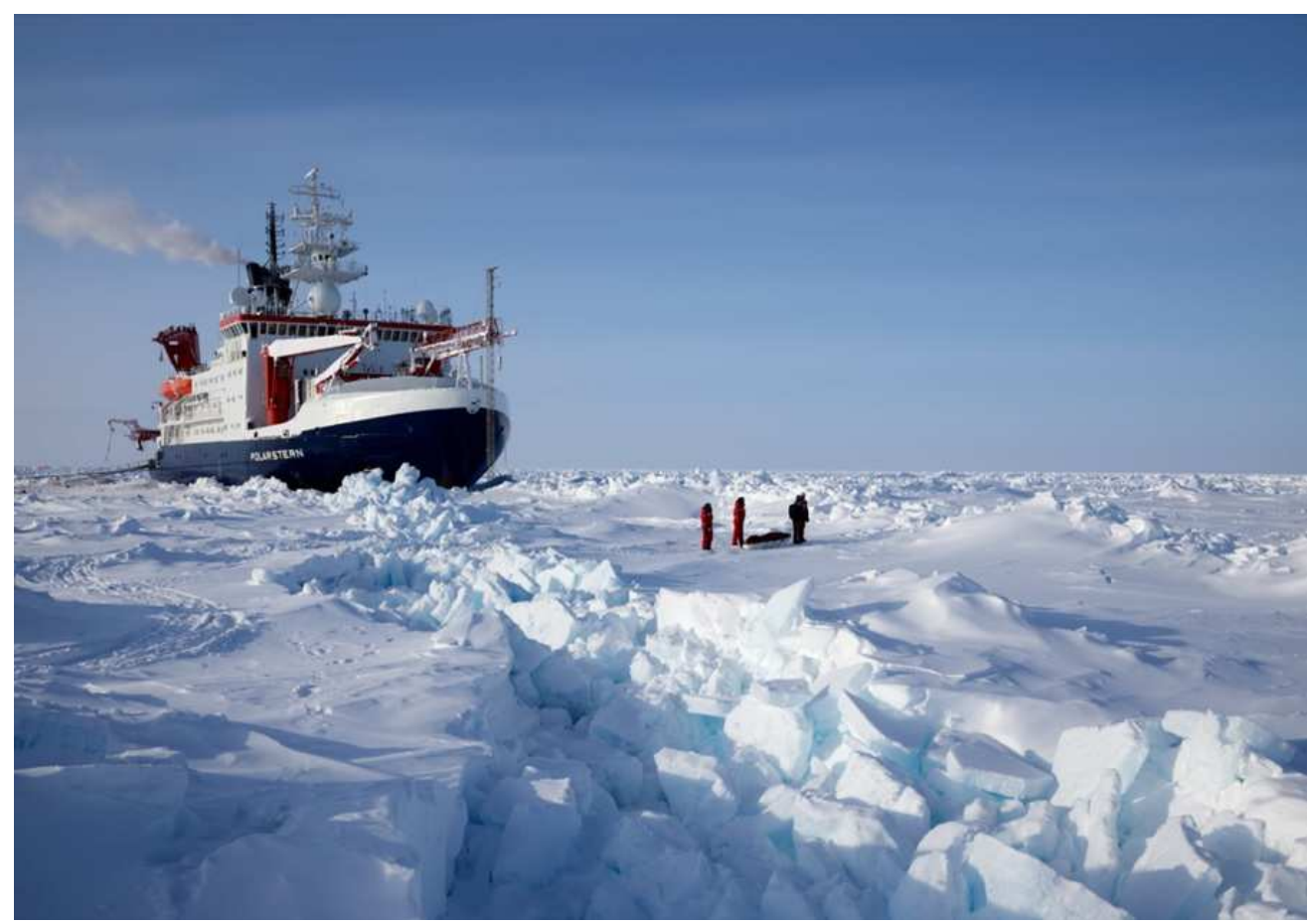

Figure 1. Icebreaker RV "Polarstern" drifting with ice of the Arctic Ocean. Visible rifted ice and ridges covered by snow on April 16, 2020

(Source: photo by Michael Gutsche/Alfred-Wegener-Institut.) 
During the research expedition MOSAiC, the icebreaker RV "Polarstern" together with the "measuring town/ice camp", set up on ice outside the icebreaker are subjected to drift and processes of occurring deformation of the Arctic ice. Fractures and cracks were observed during the initial phase of the trip. The Arctic winter period was characterized by the creation of hummocking with rifted ice and ridges. As the distance from the North Pole and the changing season of the year started, the deformation process with fracturing was seen.

\section{DRIFT OF ICEBREAKER RV “POLARSTERN” IN THE ARCTIC ICE}

The beginning of the icebreaker RV "Polarstern" drift after reaching the starting position for research $\left(\varphi=85^{\circ} \mathrm{N}\right.$ and $\left.\lambda=137^{\circ} \mathrm{E}\right)$ on October 4,2019 , began drifting in the Arctic ice field. The drift was interrupted in connection with the exchange of scientists and crew on May 16, 2020, in position $\left(\varphi=83^{\circ} \mathrm{N}\right.$ and $\lambda=$ $009^{\circ}$ E), and the ship went to the region of the Svalbard. Exiting the ice, and then returning to the Arctic again, was due to the procedure followed in connection with COVID-19 for another research leg. Figure 5 presents the drift route of the icebreaker RV "Polarstern" in the Arctic ice from October 4, 2019 to May 16, 2020, along with the expected further direction of movement as part of the MOSAiC research expedition $[7,10,11]$. 


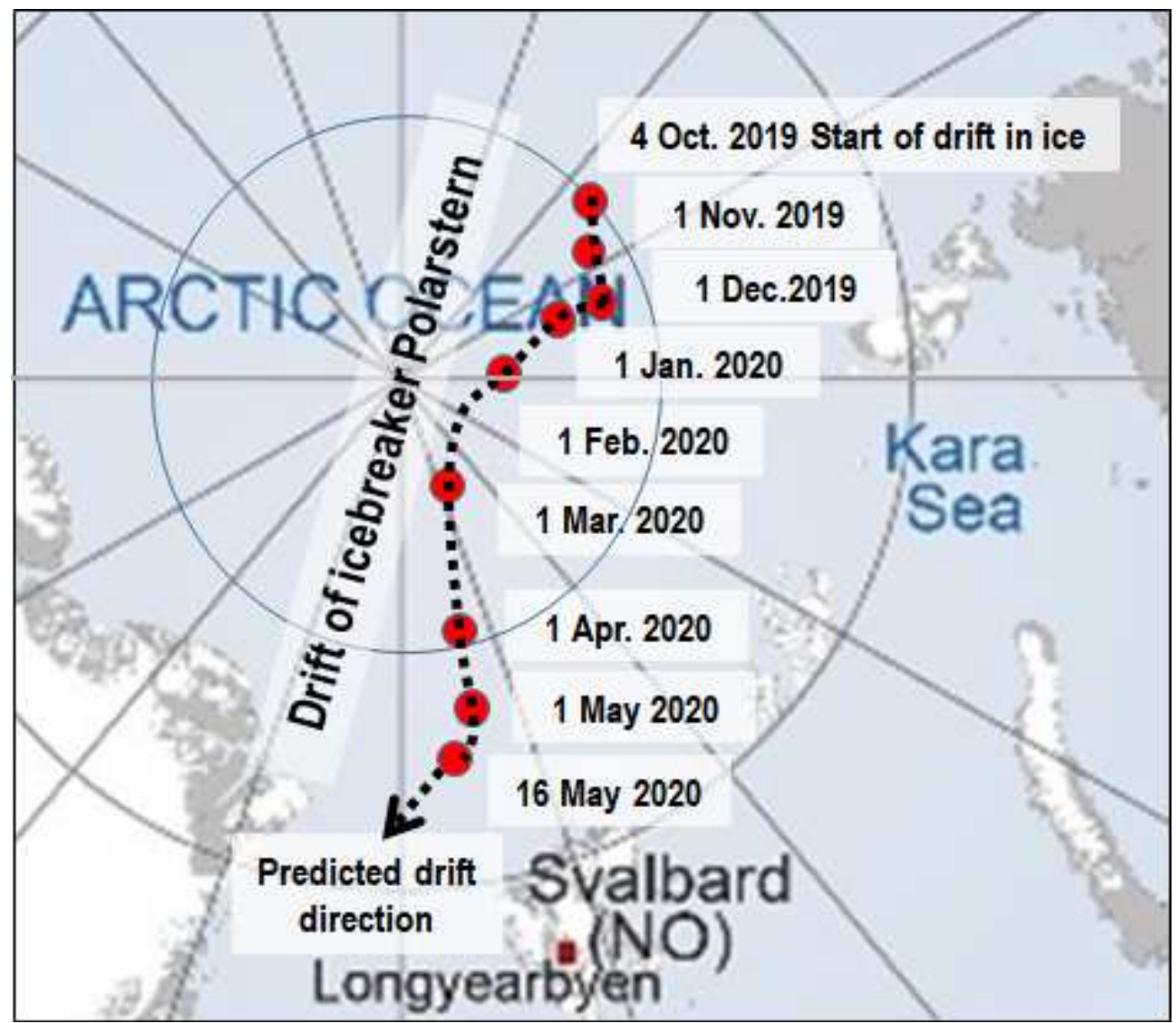

Figure 2. Drift route of the icebreaker RV "Polarstern" in the Arctic ice from October 4, 2019 to May 16, 2020 along with the expected further direction of movement as part of the MOSAiC research expedition

(Source: own study [2] based on items provided by AWI [7, 10, 11].)

Based on the AWI data, the daily drift data for the RV icebreaker "Polarstern" from October 4, 2019 to May 16, 2020 is shown in figure 6. 


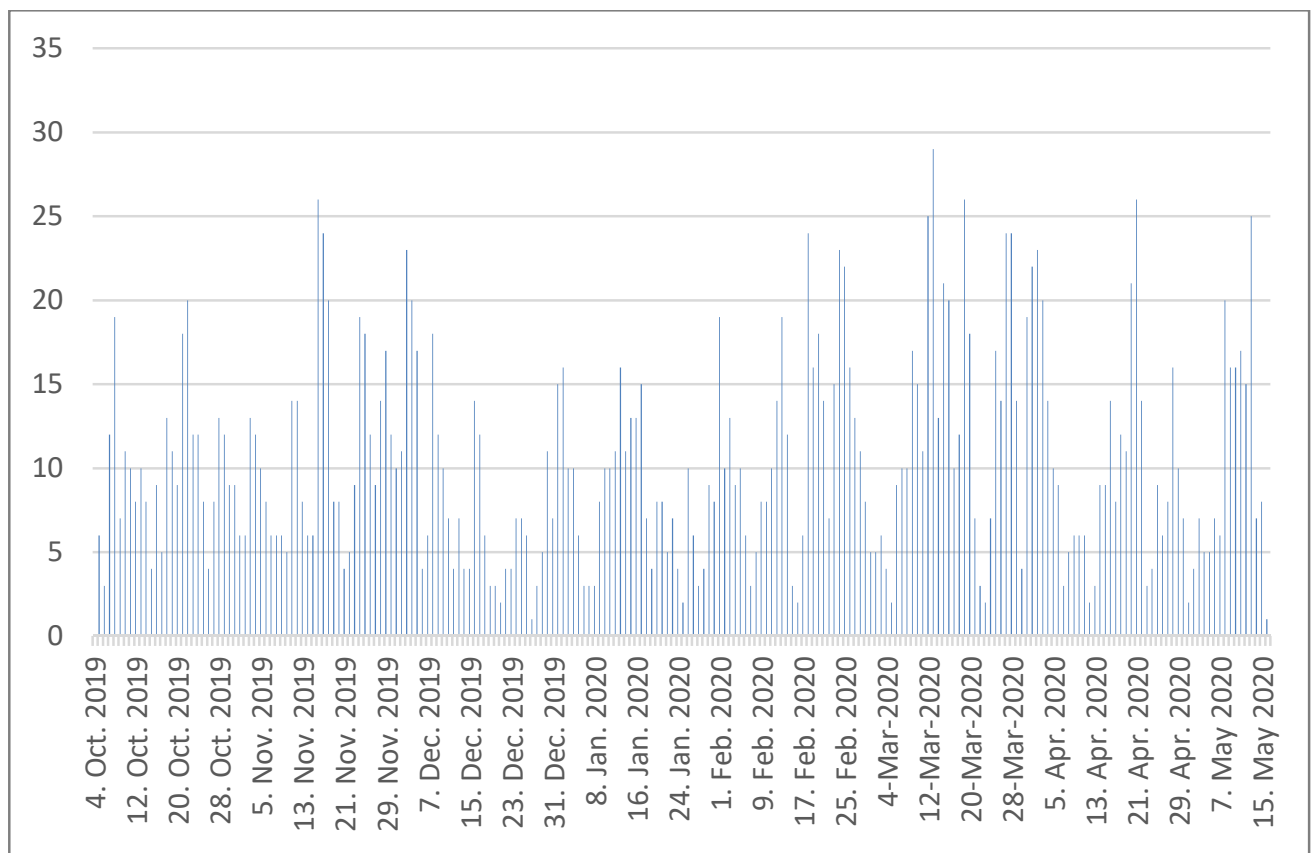

Figure 3. Daily drift of the icebreaker RV "Polarstern" from 4 October 2019 to 16 May 2020 in kilometres $(\mathrm{km})$

(Source: daily drift information based on AWI data studies [7].)

Meteorological data from RV "Polarstern" with marked values of wind direction, wind speed, barometric pressure, and daily drift in Arctic ice are shown in figure 7. By analyzing and comparing the data collected in figure 7, it can be concluded that the maximum wind speeds associated with low pressure, or a rapid change in atmospheric pressure affect the high sea ice drift values day, or some days after maximums of these data. 


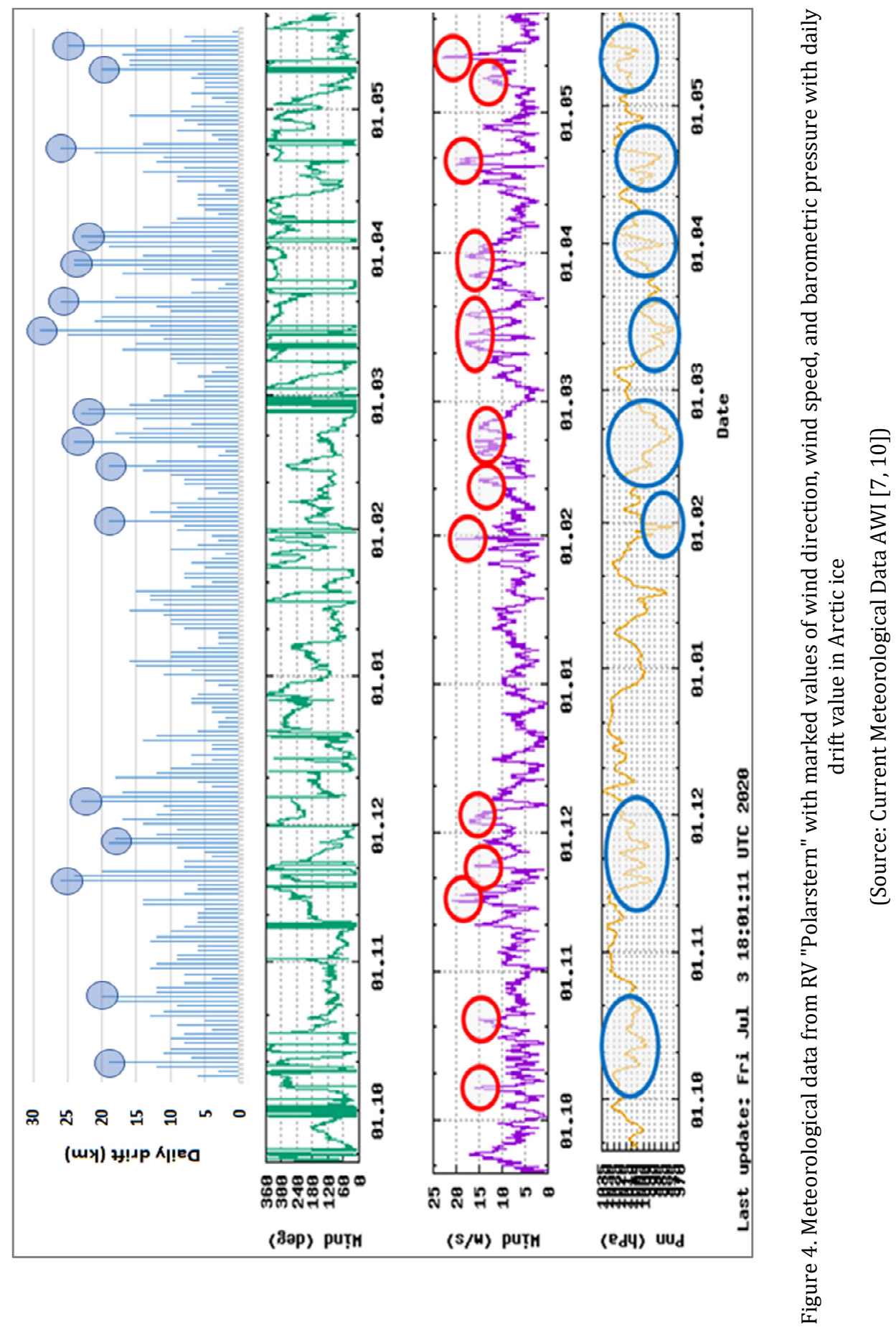


Within 225 days of October 4, 2019 at 01.00 PM to 16 May 2020 at 01.00 AM the German icebreaker RV "Polarstern", together with the "ice research town/ice camp", sailed $2335 \mathrm{~km}$. The average daily road was about 10.4 $\mathrm{km} /$ day (about $5.6 \mathrm{NM} /$ day or about $0.23 \mathrm{knots}$ ).

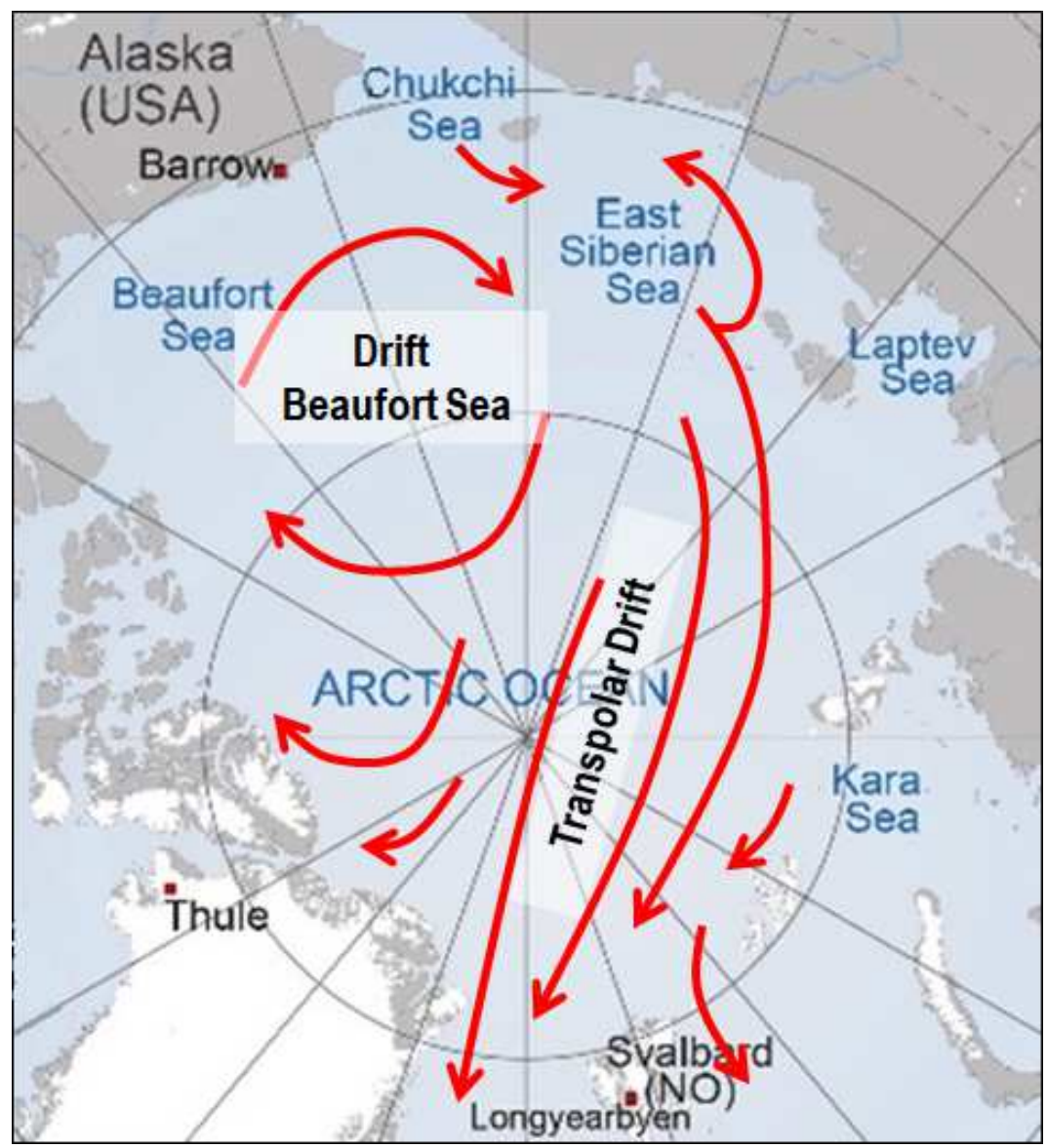

Figure 5. Ice pack drift in the Arctic Ocean

(Source: own study [2].)

The ice of the Arctic Ocean is in a constant drift. The direction and speed of the drift depend on wind conditions, and sea currents. Earlier studies of ice field drift in the Arctic Sea have determined its general course. There are two basic arctic ice circulation systems: Transpolar Drift (Arctic Drift), and Beaufort Sea Drift (Pacific Whirlpool), which are illustrated in Figure 8. Knowledge of ice conditions, 
and the phenomena associated with their movement is important for the safety of navigation in the Arctic.

\section{DISCUSSION AND CONCLUSIONS}

In the conclusion of the analysis were made of the following generalizations:

1. The following external forces influence the phenomenon of ice drift: the force of the wind on the surface of the ice, the force of the water on the drifting ice, the Coriolis force, the component gravity force parallel to the surface of the sea, and the power of the interaction of ice floes. The article mainly indicates the impact of external forces (wind) on the movement of ice masses.

2. Within 225 days of research expedition the German icebreaker RV "Polarstern" together with the "ice research town/ice camp" sailed 2,335 km, which gives the average daily road about $10.4 \mathrm{~km} /$ day (about $5.6 \mathrm{NM} /$ day or about 0.23 knots).

3. Moving along with the RV "Polarstern" ice confirmed the previously accepted because of research and observation of the direction of movement of the Arctic ice. The influence of external forces on ice has a decisive influence on the direction. The article indicates the influence of wind, and other factors were not considered.

4. Comparing the speed of the RV "Polarstern" (5.6 NM/day), and the research sailing vessel "Fram" (2.6 NM/day), one conclude that the RV "Polarstern" was traveling at more twice the speed on its road section. It can be assumed that the speed of travel probably had the thickness of ice at that time, however this thesis needs to be checked. Author does not undertake to answer this problem.

\section{ACKNOWLEDMENT}

The author extends special thanks to the Alfred-Wrgener-Institut Helmholtz Centre for Polar and Marine Research (AWI) from Bremerhaven (Germany) for permission to the use of data and images from the deck of the RV icebreaker 
"Polarstern" carrying out the Multidisciplinary drifting Observatory for the Study of Arctic Climate (MOSAiC) in the Arctic Ocean.

\section{REFERENCES}

[1] Bowditch N., The American Practical Navigation, National Geospatial-Intelligence Agency, Skyhorse Publishing, 2013.

[2] Dyrcz C., Dryf lodu morskiego, preprint for „Nautologia” No 157, Polskie Towarzystwo Nautologiczne, Gdynia 2020 [available in Polish].

[3] Dyrcz C., Meteorology and oceanology. Terms, definitions and explanations, $2^{\text {nd }}$ Edition, Polish Naval Academy, Gdynia 2019.

[4] Łomniewski K., Oceanografia fizyczna, Państwowe Wydawnictwo Naukowe, Warszawa 1969 [available in Polish].

[5] Marchenko N., Russian Arctic Seas. Navigational conditions and accidents. SpringerVerlag, Berlin-Heidelberg 2012.

[6] Mironov E. U., Opasnye ledovye javlenija dlja sudochodstva v Arktike. AANII, St. Petersburg 2010.

[7] MOSAiC -_https://follow.mosaic-expedition.org/ [access: 5 July 2020].

[8] Nansen F., Fram $w$ Arktyce, Wydawnictwo SEL, Kraków 2011 [available in Polish].

[9] Pastusiak T., Styszyńska A., Intensywny dryf lodu w rejonie wyspy Wrangla, zjawiska z nim zwiq̨zane i konsekwencje dla żeglugi, „Problemy Klimatologii Polarnej, Nr 23, 2013 p. 191-204 [available in Polish].

[10] Research ice breaker Polarstern. Current Meteorological Data https://www.awi.de/nc/en/science/long-termobservations/atmosphere/polarstern.html [access: 5 July 2020].

[11] RV Polarstern - https://mosaic-expedition.org/expedition/polarstern/ [access: 8 May 2020].

[12] Sea-Ice Information Services in the World, WMO-No. 574, World Meteorological Organization, Geneva, Edition 2017.

[13] Sea Ice Nomenclature, Summary and Purpose of Document WMO No. 259, $5^{\text {th }}$ Session of JCOMM Expert Team on Sea Ice, March 2014.

[14] Sides H., W królestwie lodu. Tragiczna wyprawa polarna USS Jeannette, Dom Wydawniczy REBIS, Wydanie I, Poznań 2016 [available in Polish].

[15] USS „Jeannette”, Log Book of the United States Navy, Naval History Homepage, http://www.naval-history.net/OW-US/Jeannette/USS_Jeannette.htm [access: 14 May 2020].

[16] Zakrzewski W., Lody na morzach, Wydawnictwo Morskie, Gdańsk 1982 [Ice on the seas available in Polish]. 


\section{DRYF LODU NA OCEANIE ARKTYCZNYM}

\section{STRESZCZENIE}

W artykule przedstawiono wyniki badań opartych na analizie historycznych i obecnych badań dryftu lodu arktycznego. Aktualne informacje na temat dryftu lodu arktycznego pochodzą z wyprawy naukowej zorganizowanej przez Alferd-Wegener-Institut (AWI) Centrum Badań Polarnych i Morskich z Bremerhaven (Niemcy) na Oceanie Arktycznym w ramach multidyscyplinarnego obserwatora dryfującego klimatu arktycznego (MOSAiC) pochodzącego z pokładu lodołamacza RV „Polarstern”. Głównym celem tego artykułu było zebranie i zilustrowanie informacji o zjawisku dryfu lodu na Oceanie Arktycznym, z uwzględnieniem danych z bieżących badań podczas wyprawy MOSAiC. Średnia prędkość ruchu lodołamacza RV „Polarstern” wraz z lodem arktycznym podczas pierwszych trzech etapów wyprawy wyniosła ponad $5 \mathrm{Nm} /$ dobę. Z drugiej strony, artykuł ma charakter popularnonaukowy i przedstawia ogólną charakterystykę dryftu lodu arktycznego ze wskazaniem generalnych kierunków i prędkości jego ruchu. Prędkości dryfu lodu w Arktyce mogą osiągnąć wyjątkowo wysokie wartości w sprzyjających warunkach. Dryf lodu morskiego osiągający wartości natężenia/intensywności bliskie granicy (niebezpieczne kryterium) w tych ekstremalnych przypadkach nazywa się „lodową rzeką”. Prędkość „lodowych rzek" może osiągnąć do 1-2 węzłów, jednak w ekstremalnych warunkach do 9 węzłów. Na podstawie danych z AWI zidentyfikowano punkty korelacji między prędkością dryftu lodu arktycznego. a prędkością wiatru i wartościami ciśnienia atmosferycznego.

\section{Słowa kluczowe:}

dryf lodu morskiego, dryf lodu arktycznego, MOSAiC 